\title{
Survei Prevalensi Ektoparasit pada Populasi Anjing Pemburu (Canis Lupus familiaris) di Kecamatan Jagong Jeget Kabupaten Aceh Tengah
}

\section{Survey of Prevalence of Ectoparasites in Dog Hunter (Canis lupus familiaris) in Jagong Jeget of Aceh Tengah District}

\author{
Alan Kurniyawan ${ }^{1}$, Teuku Reza Ferasyi ${ }^{2}$, dan Muhmmad Hanafiah ${ }^{3^{*}}$ \\ ${ }^{1}$ Program Studi Pendidikan Dokter Hewan, Fakultas Kedokteran Hewan, Universitas Syiah Kuala \\ ${ }^{2}$ Laboratorium Kesmavet, Fakultas Kedokteran Hewan, Universitas Syiah Kuala \\ ${ }^{3}$ Laboratorium Parasitologi, Fakultas Kedokteran Hewan, Universitas Syiah Kuala \\ *Email: hanafi_2015@usyiah.ac.id
}

Naskah diterima: 5 Oktober 2020, direvisi: 3 Juli 2021, disetujui: 15 Juli 2021

\begin{abstract}
Dogs are one of the domestic animals that are much loved by humans as pets because of their relatively easy maintenance. The existence of dogs is becoming popular among the public, because for some people, dogs are kept as friends, guards, hunters, scouts or drug trackers.. On the other hand, to maintain their good body condition, then need to control their health.. One of the parameters for dog health disorders is the presence of ectoparasites in their body. This study was aimed to determine the prevalence of ectoparasites of hunting dogs that are kept in Jagong Jeget District, Central Aceh Regency. Research activities have been carried out from November 2019 to February 2020. The samples used in this study were 30 hunting dog samples that owned by the member of PORBI in Jagong Jeget subdistrict by manual ectoparasites examination. The Analysis of results were conducted descriptively. The results showed that the prevalence of ectoparasites in hunting dogs in Jagong Jeget District was $83.3 \%$. In detail, this result comprised of the prevalence of ectoparasites of the Ctenocephalides canis group at $80 \%$, followed by Rhipicephalus sanguineus and Boophilus $s p$. with a prevalence of $16.6 \%$ and Trichodectes canis with a prevalence of $3.3 \%$. We concluded that there was ectoparasitic infection in hunting dogs that were kept in Jagong Jeget District and hunting dog maintenance management in Jagong Jeget District was still classified as poor.
\end{abstract}

Keywords: ectoparasites; hunting dogs; management; prevalence

\begin{abstract}
Abstrak
Anjing merupakan salah satu hewan domestik yang banyak digemari manusia sebagai hewan kesayangan karena pemeliharaannya yang relatif mudah. Keberadaan anjing sangat populer dikalangan masyarakat tertentu, karena bagi mereka, anjing dipelihara sebagai teman, penjaga, pemburu, pengintai atau pelacak narkoba. Disisi lain, untuk menjaga kondisinya tetap stabil sesuai kebutuhan pemeliharaannya, maka kesehatannya perlu dirawat dengan baik. Salah satu parameter gangguan kesehatan anjing adalah keberadaan ektoparasit dalam tubuh. Penelitian ini bertujuan untuk mengetahui prevalensi pada ektoparasit pada anjing pemburu yang di pelihara di Kecamatan Jagong Jeget Kabupaten Aceh Tengah. Kegiatan penelitian telah dilaksanakan dari bulan November 2019 sampai bulan Februari 2020. Sampel yang digunakan dalam penelitian ini adalah 30 sampel anjing pemburu yang diperiksa dari pemilik anjing pemburu anggota PORBI dari Kecamatan Jagong Jeget dengan pemeriksaan ektoparasit secara makroskopis. Data yang diperoleh dianalisis secara deskriptif. Hasil pemeriksaan menunjukkan bahwa prevalensi ektoparasit pada anjing pemburu yang di pelihara di Kecamatan Jagong Jeget adalah 83.3\%. Secara rinci ektoparasit dari kelompok kelompok Ctenocephalides canis yaitu 80\%. diikuti oleh Rhipicephalus sanguineus dan Boophilus sp. dengan prevalensi 16.6\% dan Trichodectes
\end{abstract}


canis dengan prevalensi 3.3\%. Dapat disimpulan bahwa terdapat infeksi ektoparasit pada anjing pemburu yang dipelihara di Kecamatan Jagong Jeget dengan tingkat infestasi yang tergolong tinggi.

Kata kunci: anjing pemburu; ektoparasit; manajemen pemeliharaan; prevalensi

\section{Pendahuluan}

Ektoparasit banyak dijumpai di Indonesia karena kondisi iklim dan kelembaban yang menunjang kehidupan ektoparasit sepanjang tahun (Dharmojono, 2001). Menurut penelitian yang dilakukan oleh Hadi et al. (2016) di Baharkam Mabes Polri, Depok, dilaporkan bahwa prevalensi infestasi caplak pada anjing $67,90 \%$ dengan kasus Babesiosis 8\% dan Ehrlichiosis 12\%, sedangkan di Pangkalan Udara Angkatan Udara Atang Sanjaya, Bogor, prevalensi infestasi caplak $100 \%$ dengan kasus Anaplasmosis 16\% dan Ehrlichiosis 40\%. Penelitian lain juga dilaporkan tingkat prevalensi Dirofilariasis (10\%) pada anjing liar di wilayah Kabupaten Aceh Besar (Assady et al., 2016).

Ektoparasit yang sering dijumpai pada anjing adalah caplak, kutu, tungau, dan pinjal. Jenis caplak yang sering ditemukan pada adalah Rhipicephalus sanguineus (Hadi dan Rusli, 2006). Caplak hidup di permukaan kulit hewan kemudian menghisap darah induk semang melalui pembuluh darah perifer yang berada di bawah kulit. Caplak memiliki ukuran tubuh yang cukup besar sehingga sangat mudah ditemukan pada daerah tubuh anjing. Bagian tubuh yang paling disukai caplak adalah leher, sela-sela jari, dan bagian dalam telinga (Hadi dan Soviana, 2010). Prevalensi ektoparasit dari masing-masing kelompok ektoparasit ini diketahui sangat ber-variasi dari populasi anjing satu dengan populasi anjing lainnya. Sejumlah faktor yang sering dikaitkan dengan prevalensi ektoparasit pada hewan peliharaan ini antara lain adalah karakteristik anjing (misalnya ras, jenis kelamin dan umur) dan kondisi pemeliharaannya (Omudu et al, 2010; Mosallanejadetal, 2011).

Masih banyak masyarakat di Kabupaten Aceh Tengah yang menggunakan anjing sebagai bagian dalam aktifitas sehari-hari, biasanya digunakan sebagai penjaga kebun, penjaga rumah, dan berburu. Salah satu Kecamatan yang banyak memelihara anjing adalah Kecamatan Jagong Jeget. Masyarakat Kecamatan Jagong
Jeget pada umumnya adalah pedagang, petani, dan peternak kecil. Hal yang membudaya pada masyarakat di Kecamatan Jagong Jeget adalah hobi berburu babi hutan. Kebiasaan ini dilakukan secara berkelompok dan memiliki organisasi atau perkumpulan. Berburu adalah kegiatan yang tidak asing lagi bagi masyarakat Jagong Jeget. Seiring perjalanan waktu, masyarakat pada saat ini menjadikan kegiatan berburu sebagai hobi dan sebuah ladang bisnis. Jika anjing yang dibawanya pintar berburu, maka anjing tersebut akan mempunyai nilai jual tinggi. Populasi anjing peliharaan di kecamatan Jagong Jeget cukup banyak, terdiri dari anjing lokal maupun anjing-anjing ras yang dipelihara dalam kondisi pemeliharaan yang berbeda-beda. Berdasarkan permasalahan tersebut di atas maka perlu dilakukan pnelitian untuk mengetahuan jenis dan prevaleni eks anjing pembr di Kecamatan Jagong Jeget. Hingga saat ini belum ada laporan mengenai prevalensi ektoparasit anjing yang ada di Kecamatan Jagong Jeget. Tujuan Penelitian ini untuk mengetahui tingkat prevalensi ektoparasit pada anjing pemburu di Kecamatan Jagong Jeget, Kabupaten Aceh Tengah.

\section{Materi dan Metode}

Penelitian ini menggunakan sampel 30 ekor anjing pemburu di Kecamatan Jagong Jeget, Kabupaten Aceh Tengah pada bulan November 2019 sampai bulan Februari tahun 2020. Hewan-hewan tersebut didapatkan dari 18 pemilik anjing pemburu yang tersebar di tiga desa dalam Kecamatan Jagong Jeget, yaitu Desa Paya Dedep, Desa Paya Empan dan desa Jeget Ayu dan para pemilik anjing umumnya memiliki jumlah anjing pemburu yang berbeda. Pengambilan sampel pada setiap pemilik anjing diambil minimal pada setiap pemilik 1 ekor dan maksimal 3 ekor, sesuai dengan anjing yang di miliki. Pemeriksaan sampel dilakukan di Labolatorium Parasitologi Fakultas Kedokteran Hewan Universitas Syiah Kuala Banda Aceh. 
Pemeriksaan ektoparasit pada masingmasing anjing dilakukan secara sistematis menggunakan sisir atau langsung diambil secara manual dengan tangan dan dialas dengan karton putih, yaitu dimulai dari kepala, telinga, badan, tungkai depan, tungkai belakang dan ekor. Ektoparasit yang ditemukan segera dimasukan kedalam botol sampel yang berisi alkohol $70 \%$ dan diberi label menurut kode anjing dan bagian tubuh dimana ektoparasit yang dimaksud ditemukan. Sampel spesimen ektoparasit diidentifikasi jenisnya menurut Zajac dan Gary, (2012) dengan cara meletakkan sampel di bawah mikroskop menggunakan perbesaran 40 kali untuk diamati ciri-ciri morfologi sesuai dengan Veterinary Clinical Parasitology. Untuk menentukan tingkat prevalensi anjing yang terinfeksi ektoparasit menggunakan rumus: Perhitungan Prevalensi Parasit (Puri, 2014).

Prevalensi ektoparasit $=\frac{\text { Jumlah anjing yang terinfeksi }}{\text { Jumlah anjing yang di periksa }} \times 100 \%$

Data prevalensi dari ektoparasit dan jenis-jenis ektoparasit akan dianalaisis secara deskriptif.

\section{Hasil dan Pembahasan}

Bedasarkan hasil penelitian yang dilakukan pada 30 ekor anjing pemburu yang diperiksa di Kecamatan Jagong Jeget Kabupaten Aceh Tengah. Jumlah anjing yang terinfeksi ektoparasit di Kecamatan Jagong Jeget Kabupaten Aceh Tengah seperti terlihat padaa Tabel 1 .

Dari Tabel 1 di atas diperoleh hasil bahwa anjing pemburu yang terinfestasi ektoparasit berjumlah 24 ekor dari total 30 ekor sampel. Persentase infestasi ektoparasit terbanyak terdapat di Desa Paya Dedep, yaitu 86,7\%, untuk Desa Paya Empan 77,8\% dan untuk Desa Jeget Ayu 66,7\%. Fluktuasi kejadian infestasi ektoparasit dipengaruhi oleh beberapa faktor seperti musim, suhu, kelembaban, cara pemeliharaan, dan perlakuan pemilik anjing.

Adapun perbedaan masing-masing ektoparasit yang diperoleh dalam penelitian ini antara lain ciri morfologi pinjal yang ditemukan berdasarkan kunci identifikasi Wall dan Shearer (2001) merupakan spesies Ctenocephalides canis (Gambar 1). Ctenocephalides canis memiliki sisir pronotal dan sisr gena. Sisir gena terdiri atas delapan atau sembilan duri yang tersusun secara horisontal. Bagian depan kepala memiliki bentuk miring dan memanjang. Tibi2a pada tungkai bagian belakang memiliki enam bantalan seta.

Caplak Rhipicephalus (Gambar 2) berwarna kemerahan atau coklat kehitaman. Lekuk anus terletaak lebih posterior. Pada pasangan koksa pertama terdapat celah. Basis kapituli berbentuk segi enam. Caplak ini memiliki feston dan mata, tetapi tidak memiliki hiasan pada skutum. Genus ini terdiri atas 63 spesies (Harwood dan James

Tabel 1. Hasil Pemeriksaan Terhadap Infeksi Ektoparasit pada Anjing pemburu yang dipelihara di Kecamatan Jagong Jeget Kabupaten Aceh Tengah $(\mathrm{n}=30)$.

\begin{tabular}{|c|c|c|c|c|c|c|}
\hline \multirow{2}{*}{ Lokasi } & \multirow{2}{*}{ Positif } & \multirow{2}{*}{ Negatif } & \multirow{2}{*}{ Total } & \multirow{2}{*}{ Persentase $(\%)$} & \multicolumn{2}{|c|}{ C.I 95\% } \\
\hline & & & & & lower & upper \\
\hline Desa Paya Dedep & 13 & 2 & 15 & 86.7 & -62.38 & 74.38 \\
\hline Desa Paya Empan & 7 & 2 & 9 & 77.8 & -38.97 & 49.97 \\
\hline Desa Jeget Ayu & 4 & 2 & 6 & 66.7 & -24.41 & 29.41 \\
\hline Total & 24 & 6 & 30 & 80.0 & -99.35 & 129.35 \\
\hline
\end{tabular}

Tabel 2. Prevalensi Ektoparasit pada Anjing Pemburu di Kecamatan Jagong Jeget $(n=30)$.

\begin{tabular}{lcccc}
\hline \multirow{2}{*}{ Jenis ektoparasit } & $\begin{array}{c}\text { Jumlah } \\
\text { anjing terinfeksi (ekor) }\end{array}$ & Prevalensi (\%) & \multicolumn{2}{c}{ C.I 95 \% } \\
\cline { 4 - 5 } Ctenocephalides canis & 24 & 80.0 & lower & upper \\
Rhipicephalus sanguineus & 5 & 16.6 & -112.06 & 129.35 \\
Boophilus sp & 5 & 16.6 & -112.06 & 142.06 \\
Trichodectes canis & 1 & 3.3 & -162.88 & 192.88 \\
\hline
\end{tabular}


1979). Spesies yang termasuk dalam genus ini antara lain $R$. appendiculatus, $R$. bursa, $R$. sanguineus, dan $R$. evertsi. Caplak Boophilus (Gambar 3) tidak memiliki hiasan pada skutum dan tidak memiliki festoon. Basis kapituli berbentuk segienam. Caplak ini memiliki hipostoma yang pendek, bagian lateral skutum terdapat mata, dan pada pasangan kaki pertama terdapat celah. Caplak jantan memiliki keping adanal dan keping asesori. Genus ini terdiri atas 5 spesies (Harwood dan James 1979). Spesies yang penting adalah Boophilus microplus, $B$. annulatus, dan $B$. decoloratus. Ketiganya merupakan vektor penting piroplasmosis pada sapi di Amerika, Afrika, Asia, Eropa, dan Australia. Trichodectes. (Gambar 4) memiliki bentuk tubuh yang datar, memiliki antena dan tidak memiliki sayap. Panjang tubuhnya 1-2 mm dan memiliki 4 pasang kaki. Ctenocephalides. memiliki tubuh gepeng dan tidak bersayap, Berukuran $\pm 1 \mathrm{~mm}$, berwarna coklat kemerahan dengan rambut halus disekitar tungkainya yang panjang.

Data dari Tabel 2 terlihat bahwa tingkat prevalensi ektoparasit tertinggi yang ditemukan pada seluruh sampel adalah dari kelompok Ctenocephalides canis yaitu $80 \%$ diikuti oleh Rhipicephalus sanguineus dan Boophilus sp. dengan prevalensi sama 16,6\% dan Trichodectes canis dengan prevalensi $3.3 \%$. Tinggi rendahnya prevalensi dari penelitian ini kemungkinan dipengaruhi oleh faktor lingkungannya termasuk cara pemeliharaan serta perawatannya. Kondisi lingkungan tempat penelitian dilakukan di daerah dataran tinggi dan suhu rendah, masyarakat umumnya menanam tumbuhan kopi dan tumbuhan palawija disekitarnya. Cara pemeliharaan di tempat pengambilan sampel anjing yang digunakan untuk berburu dengan cara dikandangkan, anjing akan di lepaskan sekali pada saat malam hari saja. Selain itu anjing yang dikandangkan juga dekat dengan tempat tinggal mereka sendiri. Pernyataan ini diperkuat oleh Mattalah et al. (2012) yang menyatakan bahwa banyaknya anjing yang terinfestasi ektoparasit dikarenakan adanya penularan antar anjing di dalam tempat tinggal yang sama.

Berdasarkan penelitian ini nilai prevalensi Ctenocephalides canis dan Rhipicephalus sanguineus jauh lebih banyak ditemukan dan yang paling rendah Trichodectes canis dan Boophilus sp. Hasil pengamatan dari seluruh bagian tubuh anjing menunjukkan bahwa total prevalensi ektoparasit yang ditemukan dari 30 ekor anjing adalah 83,3\%. Berdasarkan total keseluruhan, jumlah tertinggi dari kelompok Ctenocephalides canis yaitu $80 \%$ dan Rhipicephalus sanguineus dan Boophilus sp. 16,6\%, dan yang terendah Trichodectes canis 3,33\%. Banyaknya jumlah ektoparasit yang menginfeksi anjing, selain faktor lingkungan dapat juga terjadi karena faktor usia. Anjing-anjing yang digunakan untuk berburu yaitu anjing-anjing yang sudah dewasa dan tampak aktif dari prilaku bergeraknya. Priasdhika (2014) menyatakan anjing berumur tua lebih banyak terinfestasi ektoparasit mungkin berkaitan dengan sistem kekebalan tubuh anjing. Anjing yang sudah berumur tua akan mengalami penurunan sistem kekebalan dibandingkan dengan anjing yang masih muda. Faktor yang mempengaruhi sistem imun adalah usia, semakin tua usia, maka akan semakin berkurang sistem imun untuk memproduksi antibodi. Selain itu Nalitha (2016) menyatakan bahwa adanya perbedaan sebaran dan kelimpahannya suatu spesies ektoparasit sangat dipengaruhi oleh kondisi lingkungan yang tersedia, spesies-spesies tertentu dapat tersebar luas karena menjumpai kondisi lingkungan yang sesuai.

Tingginya prevalensi ektoparasit Ctenocephalides pada penelitian ini kemungkinan dapat terjadi berdasarkan penyebaran parasit dari satu anjing ke anjing lain, dengan kata lain perpindahan antar hewan karena pinjal melompat sehingga dapat dengan mudah pindah ke anjing lain tanpa harus bersentuhan. Menurut

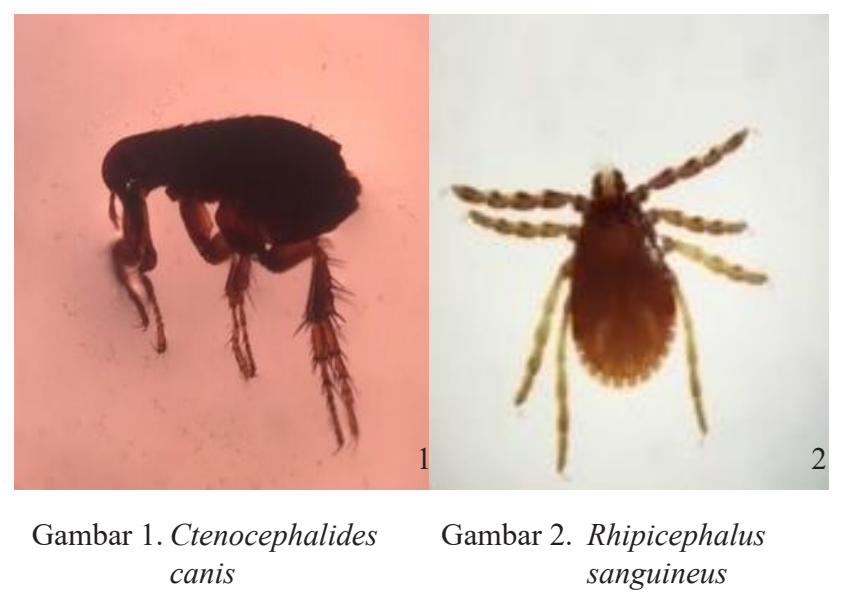


Starkey dan Stewart (2015) kondisi lingkungan mendukung keberlangsungan hidup pinjal ini. Faktor lingkungan (suhu dan kelembaban) ideal dapat mempercepat perkembangbiakan setiap stadium pinjal.Nasution(2018)juga menjelaskan Ctenochepalides canis diketahui tersebar luas diseluruh dunia karena kemampuannya beradaptasi dengan berbagai jenis lingkungan.

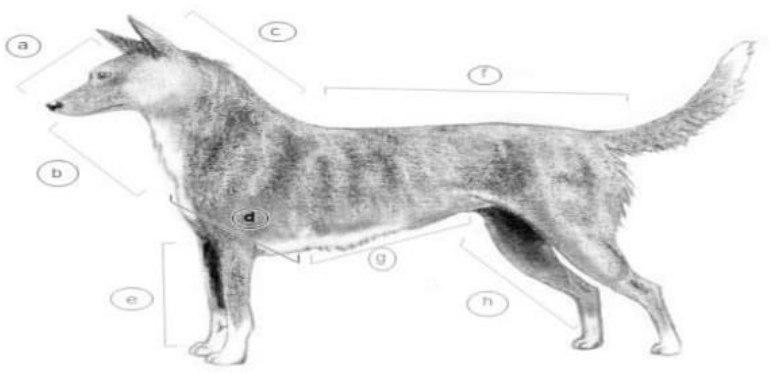

Gambar 5. Anatomi tubuh anjing (Sumber: Nurhidayat dkk, 2014).

Ket : a. Pars splanchnocranii; b. Coli ventral; c. Pars cervicales; d. Pars thorax; e. Extremitas anterior (Ossa membri thoracici); f. Pars lumbales et sacrales; g. Pars abdomen dan h. Extremitas posterior (Ossa membri pelvini).

Gambar 5 memperlihatkan bahwa bagian tubuh yang paling tinggi diinfestasi ektoparasit adalah pada bagian badan yaitu bagian thorax (Pars thorax), abdomen (Pars abdomen) dan punggung (Pars lumbales et sacrales), kemudian bagian kepala (Pars splanchnocranii), bagian leher (Coli ventral) dan paling sedikit adalah bagian kaki (Extremitas anterior (Ossa membri thoracici) dan extremitas posterior (Ossa membri pelvini). Kemungkinan lain, bagian tubuh anjing mempunyai luas permukaan terluas dibandingkan bagian kepala dan kaki disamping itu juga yang memiliki rambut lebih panjang sehingga disukai ektoparasit untuk hidup dan bersembunyi. Daerah ini sulit dijangkau anjing untuk digaruk apabila gatal. Bagian kaki anjing memiliki rambut yang lebih tipis sehingga ektoparasit tidak leluasa untuk bersembunyi juga anjing dengan mudah menggaruk dan menggigit bagian tersebut apabila merasa gatal akibat gigitan ektoparasit yang menghisap darah. Hal yang sama juga dilaporkan oleh Puri (2014) di kota Padang, bagian tubuh yang paling tinggi diinfestasi ektoparasit adalah pada bagian punggung, telinga dan paling rendah adalah kaki. Hasan (2012) mengatakan pembuluh darah besar yang dekat ke permukaan kulit adalah bagian telinga dan punggung sehingga kemungkinkan parasit dapat menghisap darah dengan mudah dan banyak.

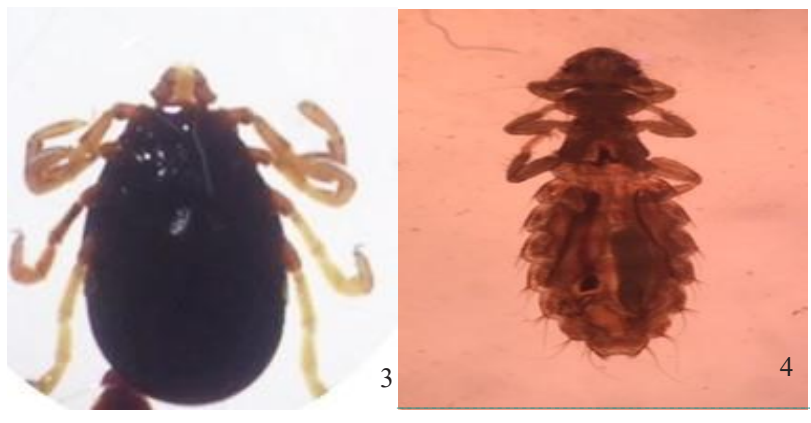

Gambar 3. Boophilus sp Gambar 4 Trichodectes canis

Fraser et al., (1991) menyatakan setiap ektoparasit mempunyai tempat yang disenangi pada tubuh inang. Priasdhika (2014) menyatakan bahwa faktor yang menyebabkan anjing jantan lebih banyak terinfestasi ektoparasit kemungkinan karena tingkah laku anjing jantan yang lebih aktif dan agresif. Anjing jantan sering dijadikan sebagai anjing penjaga dan pemacek sehingga kontak dengan anjing lain sering terjadi. Hasil ini diperkuat oleh Broom \& Fraser (2007) yang menyatakan bahwa anjing jantan memiliki sifat yang lebih dominan dibandingkan anjing betina, hal ini ditunjukkan dalam perilaku seperti mounting, mengendus-endus, dan berkelahi untuk memperebutkan wilayah. Perilaku anjing tersebut dapat menyebabkan anjing sering me-

Tabel 3. Jumlah Anjing yang Terinfeksi Berdasarkan Bagian Tubuh ( $\mathrm{n}=30)$.

\begin{tabular}{lcccccc}
\hline \multirow{2}{*}{ Jenis ektoparasit } & $\begin{array}{c}\text { Jumlah } \\
\text { anjing }\end{array}$ & Badan & Kepala & Kaki & \multicolumn{2}{c}{ C.I 95\% } \\
\cline { 5 - 8 } Ctenocephalides canis & 24 & 24 & 3 & 2 & -21.94 & 40.52 \\
Rhipicephalus sanguineus & 5 & 5 & 3 & 0 & -3.58 & 8.911 \\
Boophilus sp & 5 & 5 & 3 & 0 & -3.58 & 8.911 \\
Trichodectes canis & 1 & 1 & 0 & 0 & -3.58 & 1.767 \\
\hline
\end{tabular}


lakukan kontak langsung dengan anjing lain, sehingga infestasi ektoparasit akan meluas.

Hasil penelitian pada Tabel 3 juga menunjukkan bahwa nilai intensitas tertinggi ditemukan pada Ctenocephalides canis terhadap anjing jantan yaitu sebesar 24 individu. Selain itu pada penelitian ini diketahui cara perawatan anjing yang dilakukan oleh pemiliknya berbedabeda, hal ini dapat mempengaruhi tinggi rendahnya nilai intensitas ektoparasit yang menginfeksi anjing peliharaan. Beberapa pemilik anjing rutin memandikan anjing setiap hari atau ada juga yang hanya seminggu atau sebulan sekali bahkan ada yang tidak pernah melakukan perawatan pada anjing peliharaannya.

\section{Kesimpulan}

Berdasarkan hasil pemeriksaan pada anjing pemburu (canis lupus familiaris) yang dipelihara di Kecamatan Jagong Jeget diperoleh hasil angka prevalensi ektoparasit sangat tinggi yaitu sebesar $83,3 \%$. Dengan tingkat perincian dominan ektoparasit dari kelompok Ctenocephalides canis yaitu $80 \%$ diikuti oleh Rhipicephalus sanguineus dan Boophilus sp. dengan prevalensi $16,6 \%$ dan Trichodectes canis dengan prevalensi $3,3 \%$.

\section{Ucapan Terima Kasih}

Terima kasih kepada Kepala Laboratorium serta staf Laboratorium Parasitologi Universitas Syiah Kuala yang telah membantu dalam penyelesaian penelitian ini.

\section{Daftar Pustaka}

Assady. M., Nazaruddin., Aliza, D, Hamdani., Aisyah, S., dan Rosmaidar. (2016). Prevalensi dirofilariasis pada anjing lokal (Canis domestica) di Kecamatan Lhoknga Aceh Besar secara patologi anatomis. Jurnal Medika Veterinaria. 10(2):109111.

Broom, D. M., dan A. F. Fraser. 2007. Domestic Animal Behavior and Welfare. Cambridge (UK) : CAB International.

Dantas-Torres. (2010). Biology and ecology of the brown dog tick, Rhipicephalus sanguineus. Parasites and Vectors. 3(26):1-10

Dharmojono. (2001). Kapita Selekta Kedokteran Hewan. Edisi ke-1. Pustaka Populer Obor. Jakarta.

Fraser, C. M. J. A., Bergeron, A., Maysand, S., dan Aiello,E. (1991). The Merck Veterinary Manual. Ed ke-7. USA: Merck and Co Inc.

Hadi, U.K., dan Rusli, V.L. (2006). Infestasi caplak anjing Rhipicephalus sanguineus (Parasitiformes: Ixodidae) di daerah Kota Bogor. Jurnal Medis Veteriner Indonesia. 10(2):55-60.

Hadi, U.K., dan Soviana, S. (2010). Ektoparasit: Pengenalan, Identifikasi, dan Pengendaliannya. Ed ke- 3. Bogor (ID): IPB Press.

Hadi, U.K., Soviana, S., dan Pratomo, I.R.C. (2016). Prevalence of ticks and tick-borne diseases in Indonesian dogs. Journal of Veterinary Science and Technology. 7(3):1-7.

Hasan, M.,Abubakar, M., Muhammad., G., Khan. M. N and Hussain, M. (2012). Prevalence of Ticks Infestation (Rhipicephalus sanguineus and Hyalomma anatolicum anatolicum) in Dogs in Punjab, Pakistan. Veterinarianitaliana. 48(1): 95-98

Matallah, F., Benakhla, A., Medjouel, L., Matallah, S. (2012). Tick Infestation of Dogs and Prevalence of Canine Babesiosis in The North-East of Algeria; Area of El-Tarf. American Eurasian Journal of Sustainable Agriculture. 6(3): 126-134.

Nasution, A.Y.A. 2018. KajianParasitosis pada Anjing dan Kucing Peliharaan yang Datang ke Klinik Hewan di Jakarta Utara. Bogor: IPB.

Nalitha, F.F., Muhatma, R dan Muhammad, A. (2016). Prevalensi Ektoparasit pada Populasi Anjing Peliharaan (Canis lupus familiaris) di Kota Payakumbuh. Riau. Skripsi. Universitas Riau.

Nurhidayat, Nisaâ€, C., Setijanto, H., Agungpriyono, A., Novelina, S., Supratikno. (2014). Osteologi dan Miologi Veteriner. Cetakan Pertama. PT Penerbit IPB Press 
Omudu, E.A., Okpe, G., dan Adelusi, S.M. (2010). Studies oi Dog Population In Makurdi, Nigeria (II): A Survey of Ectoparasite Infestation and It's Public Health Implications. Journal of Researches in Forestry, Wildlife and Enviroment. 2(1): 94 - 106.

Puri, K. M, Dahelmi dan Mairawita. 2014. Ectoparasite Species and Their Prevalence on Pet Dogs. Jurnal Biologi Universitas Andalas. 3(3): 183-187.

Priasdhika, G. (2014). Studi Infestasi Ektoparasit pada Anjing di Pondok Pengayom Satwa Jakarta. Bogor: Institut Pertanian Bogor. Prajanto, Agus A. 2004. Anjing Sehat dan Pintar. Jakarta: PT Agromedia.
Starkey L dan Stewart J. 2015. Feline Arthropods. Today is Veterinary Practice. 59-64.

Wall, R., and Shearer, D. 2001. Veterinary Ectoparasites: Biology, Pathology and Control. 2nd ed. lowa: Iowa State Univ Press

Zajac, A.M., Gary, A., Conboy. (2012). Veterinary Clinical Parasitology. $7^{\mathrm{Ed}}$. London: Blackwell Publishing. 